\section{Adhesion to a Lithium Disilicate Glass Ceramic Etched with Hydrofluoric Acid at Distinct Concentrations}

\author{
Catina Prochnow ${ }^{1}$, Andressa Borin Venturini ${ }^{1}$, Rafaella Grasel ${ }^{1}$, André \\ Gundel2 $^{2}$, Marco Cícero Bottino ${ }^{3}$, Luiz Felipe Valandro ${ }^{1}$
}

'Post-Graduate Program in Oral Science (Prosthodontics Unit), Dental School, UFSM Universidade Federal de Santa Maria, Santa Maria, RS, Brazil. ${ }^{2}$ School of Physics, UNIPAMPA - Universidade Federal do Pampa, Bagé, RS, Brazil.

${ }^{3}$ Department of Cariology, Restorative Sciences and Endodontics, University of Michigan School of Dentistry, Ann Arbor, Michigan, USA

Correspondence: Luiz Felipe Valandro, Rua Floriano Peixoto, 1184, 97015-372, Santa Maria, RS, Brazil. Tel.: +55.55.3220.9276. e-mail: Ifvalandro@hotmail.com.

\begin{abstract}
Key Words: atomic force microscopy, conditioning, microshear, surface treatment, vitreous ceramic.
\end{abstract}

\section{Introduction}

The addition of lithium disilicate crystals in glass ceramics improves strength and durability over conventional dental ceramics (1). Nonetheless, the longevity and success of lithium disilicate ceramic restorations is directly related to achievement of the bonding process (2). Prior to resin cementation, the protocol for glass ceramic restorations requires etching with hydrofluoric acid (HF) and silane application on the intaglio ceramic surface (3). Retention is well achieved with these procedures $(2,4)$ and, according to a recent study, when used separately, they do not promote satisfactory results (5).

Ceramic etching is a dynamic process and its result varies owing to acid concentration, etching time, substrate constitution, physical structure, and surface topography (6). Basically, the acid reacts with the ceramic glass matrix, selectively removing it and exposing the crystalline structure (5). The inner surface of all ceramic restoration becomes rough, with increased surface area available for bonding and with undercuts, promoting micromechanical interlocking with resin cement $(4,7)$.

As consequence of the surface treatment, the ceramics' surface energy is increased and the contact angle between the ceramic and resin cement decreased by removal or stabilization of surface defects, providing the needed wettability for the silane and resin cement to infiltrate into irregularities of the conditioned ceramic surface (5). The previous application of silane allows resin cement to chemically bond to the intaglio ceramic surface (3). Silane works as a bi-functional molecule, in which one extremity reacts with a glassy phase of the ceramic surface, while the other extremity copolymerizes with methacrylate groups within the organic matrix of resin cements by siloxane bonds, determining an adhesive cementation (4). In this way, silane improves the durability and bond strength of ceramic restorations (4).

On the other hand, it has been pondered that overetching can weaken glass-ceramics $(6,8)$, because removal of the glassy matrix and the defects population created on the ceramic surface are related to time and concentration of hydrofluoric acid (8). According to Addison et al. (6), HF acid etching increases the maximum peak to trough amplitude, thus increasing the pre-existing asymmetry in the survival probability distributions and reliability of the fracture strength data. Also, the presence of defects, as created by HF etching, is associated with the stress propagation from flaws at the bonding surface of dental porcelain restorations $(6,8)$.

Moreover, $\mathrm{HF}$ is capable of causing severe trauma to soft tissues, considering it is a hazardous substance and extremely corrosive. Epithelial necrosis was observed in rat skin $24 \mathrm{~h}$ after HF exposure (9). In addition, skin damage 
showed a strong extension into deeper skin layers with increasing HF concentration and exposure duration (10).

Taking into account these premises and concepts, an optimal concentration of hydrofluoric acid required to promoting durable bond strengths without weakening glass ceramics remains uncertain. Thus, could etching with hydrofluoric acid at distinct concentrations $(1 \%, 3 \%, 5 \%$, and $10 \%$ ) promote similar resin adhesion to lithium disilicate ceramic? For this reason, the purpose of the current study was to examine the effects of different $\mathrm{HF}$ concentrations on the contact angle, roughness, and durability of bond strength between a lithium disilicate-based glass ceramic (IPS e.max CAD) and a resin cement. The hypotheses tested were: 1) HF acid at different concentrations will influence the values of bond strength, roughness, and contact angle and 2) storage and thermocycling will decrease bond strength values when compared to dry conditions.

\section{Material and Methods Contact Angle Measurement}

Twenty-five ceramic slices $\left(12 \times 7 \times 2 \mathrm{~mm}^{3}\right)$ were prepared from prefabricated ceramic blocks IPS e.Max CAD (Ivoclar Vivadent, Schaan, Liechtenstein). Ceramic blocks were sectioned using a diamond disc at low-speed, under water-cooling, and in a cutting machine (Isomet 1000, Buehler, Lake Bluff, IL, USA). The surface was flattened and polished using silicon carbide papers (\#400- \#600-, and \#1200-grit; 3M, Sumare, SP, Brazil). Then, all ceramic slices were crystallized (P500, Ivoclar-Vivadent; $840^{\circ} \mathrm{C}$, vacuum - $7 \mathrm{~min}$ ), followed by cleaning in an ultrasonic device (Vitasonic, Vita Zanhfabrik, Bad Sackingen, Germany) for 10 min using isopropyl alcohol.

The ceramic samples were randomly assigned (www. randomizer.org) to 5 groups $(\mathrm{n}=5)$ according to the surface conditioning method (Table 1). The ceramic surfaces were etched using 4 concentration of hydrofluoric acid with the same procedures: etching for $20 \mathrm{~s}$, rinsing with air-water spray for $30 \mathrm{~s}$, drying for $30 \mathrm{~s}$, and ultrasonic cleaning

Table 1 Experimental design.

\begin{tabular}{|c|c|c|c|}
\hline & $\begin{array}{l}\text { Surface conditioning for contact } \\
\text { angle and roughness analyses }\end{array}$ & $\begin{array}{l}\text { Surface conditioning } \\
\text { for } \mu \text { SBS }\end{array}$ & $\begin{array}{l}\text { Storage } \\
\text { condition* }\end{array}$ \\
\hline CTRL & Non-etched control & - & - \\
\hline HF1 & \multicolumn{2}{|c|}{ Etching with hydrofluoric acid $1 \% \%^{* * *}$} & Without / With \\
\hline HF3 & \multicolumn{2}{|c|}{ Etching with hydrofluoric acid 3\%** } & Without / With \\
\hline HF5 & \multicolumn{2}{|c|}{ Etching with hydrofluoric acid 5\%** } & Without / With \\
\hline HF10 & \multicolumn{2}{|c|}{ Etching with hydrofluoric acid 10\%**** } & Without / With \\
\hline
\end{tabular}

${ }^{*}$ Storage $\left(37^{\circ} \mathrm{C}\right.$ for 150 days) and thermocycling $\left(12,000\right.$ cycles; $5^{\circ} \mathrm{C}$ and $\left.55^{\circ} \mathrm{C}\right)$. ***xperimentally formulated, FGM. ${ }^{* * *}$ Condac Porcelana 10\%, FGM; Santa Catarina, Brazil.
(Vitasonic, Vita Zanhfabrik) in distilled water for $5 \mathrm{~min}$, meanwhile the control group (without hydrofluoric acid etching) was subject only to ultrasonic cleaning.

The contact angle via the sessile drop technique was measured using a goniometer (Drop Shape analysis, model DSA 30S, Kruss GmbH, Hamburg, Germany), which was connected to a computer with dedicated software (DSA3, V1 .0.3-08, Kruss) to assess the contact angles. At room temperature $\left( \pm 24^{\circ} \mathrm{C}\right)$, one drop $(11 \mu \mathrm{l})$ of distilled water was placed at the center of the untreated and treated ceramic surfaces (Table 1) using a needle. The contact angle was measured after $5 \mathrm{~s}$.

\section{Microshear Bond Strength Test}

Preparation of the samples: Eighty $(\mathrm{N}=80)$ ceramic blocks $\left(12 \times 7 \times 2 \mathrm{~mm}^{3}\right)$ were prepared as aforementioned. The blocks were embedded in plastic rings with self-curing acrylic resin (JET Clássico; Campo Lindo Paulista, SP, Brazil). Then, all the samples were cleaned in an ultrasonic device (Vitasonic, Vita Zanhfabrik) with isopropyl alcohol for 10 $\min$.

Study design (ceramic surface conditioning): The ceramic blocks were randomly assigned (www.randomizer. org) to 8 study groups (10 blocks per group), according to the hydrofluoric acid concentration, in 4 levels, namely $1 \%$ (HF1), 3\% (HF3), 5\% (HF5), and 10\% (HF10), and storage at 2 sublevels (baseline and aging condition) (Table 1). Microshear bond strength tests did not have a control group (without hydrofluoric acid etching). The experimental unit was the resin cement cylinder.

The etching procedures were made as aforementioned for contact angle analysis (etching for $20 \mathrm{~s}$, rinsing with airwater spray for $30 \mathrm{~s}$, and drying for $30 \mathrm{~s}$ ). The blocks were then cleaned in an ultrasonic bath with distilled water (5 $\mathrm{min}$ ) to remove debris and precipitates; the bonding surface was air-dried and the silane coupling agent (Monobond Plus, Ivoclar Vivadent) was applied actively for $15 \mathrm{~s}$ on the surfaces, and kept reacting for more $45 \mathrm{~s}$, as recommended by the manufacturer.

Cementation: Four starch tubings (0.96 $\mathrm{mm}$ internal diameter; $1 \mathrm{~mm}$ high; Renata, Pastificio Selmi, Londrina, Brazil) (11) were placed over each bonding surface $(n=40)$. The tubes were fixed with sticky wax (Lysanda, Sao Paulo, Brazil), and the dual cure resin cement (Multilink, Ivoclar Vivadent) was applied inside the tubes and photo-cured (Radii-cal, SDI, Bayswater, WA, Australia) for $40 \mathrm{~s}$. Then, the samples were stored in distilled water at $37^{\circ} \mathrm{C}$ for $24 \mathrm{~h}$. After this period, the starch tubings were carefully removed and the specimens were analyzed using a 
stereomicroscope (Discovery V20, Carl-Zeiss, Gottingen, Germany) at $40 \times$ magnification for examination of the margin of the adhesive zone. Specimens with gaps, bubble inclusions, or other defects at the margin were discarded before testing.

Storage and microshear tests: Samples from baseline conditions were tested in shear ( $24 \mathrm{~h}$ after cementation), while samples under aging conditions were stored for 150 days in distilled water at $37^{\circ} \mathrm{C}$ and thermocycled $(12,000$ cycles; $5-55^{\circ} \mathrm{C}$; dwelling time: $30 \mathrm{~s}$; transfer time: $2 \mathrm{~s}$ ) (Nova Etica, Vargem Grande do Sul, SP, Brazil).

For microshear testing, the samples were placed in a jig attached to a universal testing machine (EMIC DL-2000, EMIC, Sao Jose dos Pinhais, PR, Brazil). A thin stainless steel wire loop $(\phi=0.20 \mathrm{~mm})$ was placed as close as possible to the ceramic surface for contact with the lower half-circle of the cylinder. The load was applied (load cell $0.1 \mathrm{KN}$ ) at a crosshead speed of $0.5 \mathrm{~mm} / \mathrm{min}$ until fracture occurred. Care was taken to keep the resin cement cylinder in line with the center of the load cell and the wire loop parallel to the load cell's movement direction and to the bonding interface. The bond strength ( $\mathrm{R}$ in $\mathrm{MPa}$ ) was calculated by equation: $R=F / A$; where " $F$ " is the load required for failure of the specimen $(N)$, and " $A$ " is the interface area of the specimen $\left(\mathrm{mm}^{2}\right)$. The bonded area $\left(A\right.$ in $\left.\mathrm{mm}^{2}\right)$ was equal for all samples, and was obtained by $A=\pi^{*}(r)^{2}$, where $\pi=3.1416$ and $r=0.48 \mathrm{~mm}$; i.e., $A=3.1416^{*}(0.48)^{2}=0.72 \mathrm{~mm}^{2}$. Figure 1 presents the steps to perform bond strength tests: starch tubing positioning with sticky wax, starch tubing filled up by the resin cement, starch tubing after one day of water storage and the setup used to michoshear bonding tests.

\section{Fracture Pattern}

The fracture pattern was determined under a stereomicroscope (Discovery V20, Carl-Zeiss), and classified into 2 types: 1) predominantly adhesive failure at the interfacial region between the resin cement and ceramic (ADHES); 2) cohesive failure at the cement (COHES-cem).

\section{Micromorphological Analysis}

In order to observe the surface alterations of the etched ceramic using different $\mathrm{HF}$ acid concentrations, specimens without hydrofluoric acid etching and etched with all tested HF acid concentrations were evaluated under field emission

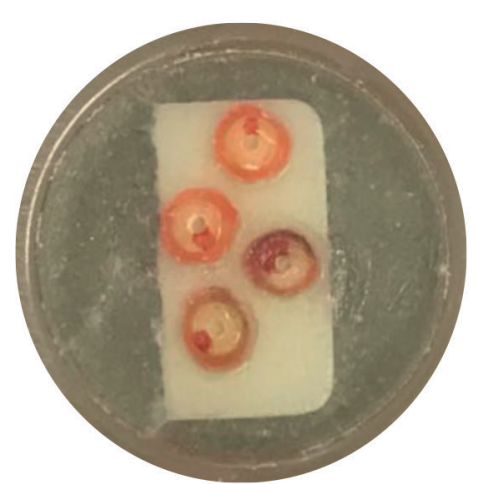

Starch tubing positioning with sticky wax.

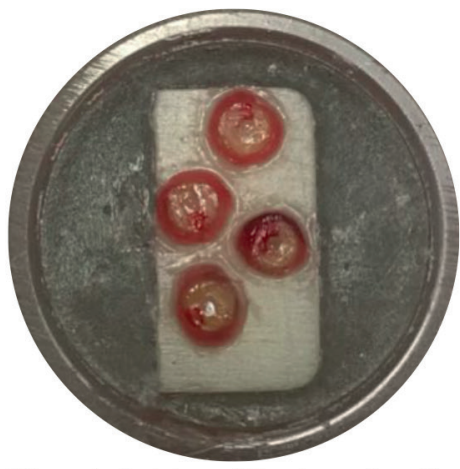

Starch tubing filled up by the resin cement.

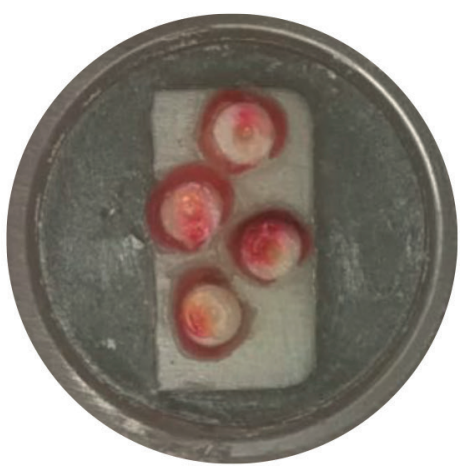

Starch tubing after one day of water storage $\left(37^{\circ} \mathrm{C}\right)$.

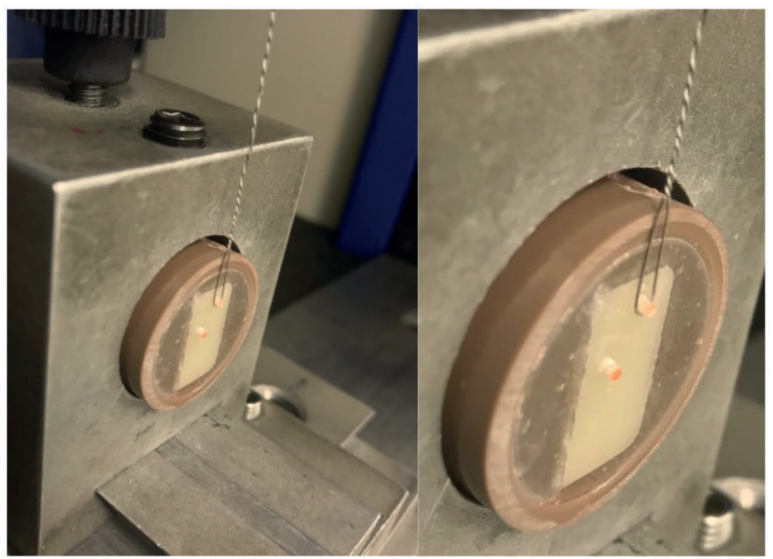

Setup used to michoshear bond strength tests.

Figure 1. Illustrative images for the steps to perform bond strength tests. 
scanning electron microscopy (FE-SEM) (FEI Inspect F50, FEl, Hillsboro, OR, USA) at distinct magnifications. For these analyzes, the specimens were sputter-coated with gold-palladium.

\section{Roughness Analysis by Atomic Force Microscopy (AFM)}

Surface roughness measurements $(10 \mu \mathrm{m} \times 10 \mu \mathrm{m})$ were obtained in four specimens per group (Table 1 ; control group and etched with 1, 3, 5 and 10\% hydrofluoric acid), using a non-contact mode and PPP-NCL probes (Nanosensors, force constant $=48 \mathrm{~N} / \mathrm{m}$ ) mode of the AFM device (Agilent 5500 Equipment, Agilent Technologies, Santa Clara, CA, USA). When using the AFM in non-contact mode, surface features are observed at a nano-scale level and any detected roughness is shown as small grains or particles. The use of this method has many advantages; the most important being the ability to collect 3D surface analysis and phase type of data, as well as the numeric data of surface properties. The numeric surface roughness parameters evaluated were average surface roughness (Sa) and the average distance among the 5 highest peaks and the 5 major valleys (Sz) values. AFM micrographs were analyzed using scanning probe microscopy data analysis software (GwyddionT"' version 2.33, GNU, Free Software Foundation, Boston, MA, USA). In addition, topographical images were also collected.

\section{Statistical Analysis}

A resin cement cylinder was used as the experimental unit for the bond data analysis. Cohesive failures were excluded from the statistical analysis, since those failures did not represent the real bond strength. All the data were presented as mean and standard deviation (SD) values. A normal distribution was assumed after the Shapiro-Wilk test for bond strength data. Consequently, the two-way ANOVA and Bonferroni tests $(\alpha=.05)$ were performed to compare results from baseline and aging conditions and to compare data among the different groups. One-way ANOVA and the post-hoc Tukey's test were used to evaluate the contact angle and AFM roughness data $(\alpha=.05)$. All statistical analysis were performed by Software Stata 14.2 (Stata Corp, College Station, TX, USA)

\section{Results}

\section{Contact Angle}

The non-etched group (CTRL) achieved the highest contact angles, followed by the HF1 group. The lowest contact angle values were HF3, HF5, and HF10, which were statistically similar (Table 2). Figure 2 presents representative contact angle images for each surface treatment.

\section{Microshear Bond Strength}

The total number of tested samples in baseline and

Table 2 Means and standard deviation of bond strength data (MPa) as a function of storage condition, total number of tested samples in conditions without and with aging, total number of pre-tested failures (PTF) during thermocycling (TC), contact angle, and roughness (Sa and Sz parameters - in $\mathrm{nm}$ )

\begin{tabular}{|c|c|c|c|c|c|c|c|c|}
\hline & \multicolumn{2}{|c|}{ Mean bond strength } & \multirow{2}{*}{$\begin{array}{c}\text { Total tested } \\
\text { samples } \\
\text { without aging }\end{array}$} & \multirow{2}{*}{$\begin{array}{c}\text { Total tested } \\
\text { samples with } \\
\text { aging* }\end{array}$} & \multirow{2}{*}{$\begin{array}{c}\text { Total number } \\
(\%) \text { of PTF } \\
\text { during TC }\end{array}$} & \multirow{2}{*}{$\begin{array}{l}\text { Contact } \\
\text { angle }\end{array}$} & \multicolumn{2}{|c|}{ Roughness } \\
\hline & Without aging & With aging* & & & & & $S a(\mathrm{~nm})$ & $S z(\mathrm{~nm})$ \\
\hline CTRL & - & - & - & - & - & $28.4 \pm 1.5^{\mathrm{A}}$ & $9.2 \pm 3.2^{\mathrm{C}}$ & $134.5 \pm 25.1^{\mathrm{B}}$ \\
\hline HF1 & $11.2 \pm 4.5^{\mathrm{Ba}}$ & $1.8 \pm 2.9^{\mathrm{Bb}}$ & $40^{* * *}$ & 4 & $36(90 \%)$ & $15.9 \pm 2.5^{\mathrm{B}}$ & $24.9 \pm 3.1^{\mathrm{BC}}$ & $205.3 \pm 29.6^{\mathrm{B}}$ \\
\hline HF3 & $13.9 \pm 3.9^{\mathrm{ABa}}$ & $7.8 \pm 6.1^{\mathrm{Ab}}$ & $38^{* * *}$ & 25 & $15(37.5 \%)$ & $7.8 \pm 0.4^{\mathrm{C}}$ & $30.4 \pm 2.4^{\mathrm{B}}$ & $275.0 \pm 43.3^{\mathrm{B}}$ \\
\hline HF5 & $15.9 \pm 2.9^{\mathrm{Aa}}$ & $11.0 \pm 7.5^{\mathrm{Ab}}$ & $39^{* * *}$ & 33 & $7(17.5 \%)$ & $8.3 \pm 2.9^{C}$ & $56.6 \pm 18.2^{\mathrm{A}}$ & $563.8 \pm 185.5^{\mathrm{A}}$ \\
\hline HF 10 & $14.5 \pm 5.2^{\mathrm{ABa}}$ & $9.8 \pm 7.5^{\mathrm{Ab}}$ & $37^{* * *}$ & 27 & $13(32.5 \%)$ & $10.4 \pm 2.1^{\mathrm{C}}$ & $52.5 \pm 2.4^{\mathrm{A}}$ & $469.8 \pm 25.4^{\mathrm{A}}$ \\
\hline
\end{tabular}

${ }^{*}$ Storage $\left(37^{\circ} \mathrm{C}\right.$ for 150 days) and thermocycling $\left(12,000\right.$ cycles; $5^{\circ} \mathrm{C}$ and $\left.55^{\circ} \mathrm{C}\right)$. Means in the same column with the same capital letter are statistically similar. Different lowercase letters mean statistical difference between storage conditions. ${ }^{* *}$ Forty (40) resin cement cylinders were produced for each condition; for baseline groups, specimens with bubbles and defects in the interface were not tested; for aged groups, all the specimens were checked before the storage period, being the non-tested samples all pre-test failures (during termocycling).

Control (non-etched) $28.4 \pm 1.5^{\mathrm{A}}$

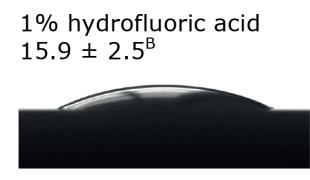

$3 \%$ hydrofluoric acid $7.8 \pm 0.4^{\mathrm{C}}$
$5 \%$ hydrofluoric acid $8.3 \pm 2.9^{\mathrm{C}}$
$10 \%$ hydrofluoric acid $10.4 \pm 2.1^{C}$
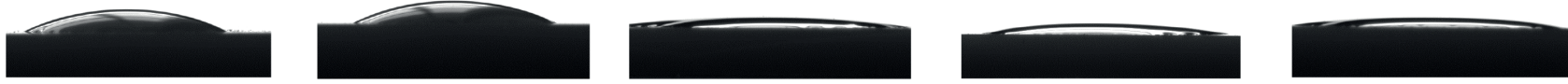

Figure 2 Images and means \pm SD (in degrees) of contact angle measurements of surfaces subjected to the following conditions: non-etched (CTRL); etched for 20 s with 1\%, 3\%, 5\%, and 10\% hydrofluoric acid. The same superscript letters indicate no significant differences (Tukey's test; $\alpha=5 \%$ ). 
aged groups, and the number/percentages of specimens that failed during the aging process (pre-test failures) are listed in Table 2. The HF1 group had the highest percentage of pre-test failure. To provide a fair comparative evaluation among the tested groups, the specimens that failed prior to testing were considered in the statistical analysis. For this purpose, the minimum value of $\mu$ SBS obtained in each group was assigned to each prematurely debonded specimen (12).

Two-way ANOVA revealed that HF concentration $(p<0.0001)$, aging $(p<0.0001)$, and interaction $(p<0.0001)$ had a statistically significant effect on the bond results. For the baseline condition, the HF3, HF5, and HF10 groups were statistically similar. Bonferroni's test showed that HF5 was significantly higher than HF1 $(p=.012)$; however, HF1 was statistically similar to HF3 and HF10. After aging, HF3, $\mathrm{HF5}$, and HF10 were statistically similar and had the highest bond results, while HF1 had the lowest $(p=0.0001)$ (Table 2).

In terms of bond stability, the storage/thermocycling had a negative effect for all HF acid concentrations: the bond values reduced after aging, compared to their counterpart baseline condition (Table 2).

\section{Fracture Pattern}

Even with a different number of tested specimens, all groups presented similar percentiles of adhesive and cohesive (in cement) failures (Table 3).

\section{Micromorphological Analysis}

FE-SEM analyses (Fig. 3) showed slight topographical changes in the lithium disilicate surface etched with HF1 acid, when compared to the non-etched condition (CTRL). The 3\% hydrofluoric acid was able to produce minor topographical changes, but as expected, higher hydrofluoric acid concentrations (5 and 10\%) created more irregular and porous surfaces by a stronger removal of the glassy matrix and with crystals pulling out from the surface.

\section{Roughness analysis by AFM}

$\mathrm{HF}$ acid in concentrations of $5 \%$ and $10 \%$ promoted rougher surfaces for $\mathrm{Sa}$ and $\mathrm{Sz}$ parameters. 1\% HF acid was not able to change the surface roughness when compared with the non-etched surface (CTRL) (Table 2; Fig. 4).

\section{Discussion}

The first hypothesis of the present study was partially accepted, since different hydrofluoric acid concentrations significantly influenced the contact angle values (Table 2; Fig. 2), and bond strength, but $1 \%$ and $3 \%$ hydrofluoric acid were not able to promote changes on parameters evaluated for roughness. All groups presented a statistically significant decrease in bond strength values after aging, meaning that the second hypothesis was accepted. Considering the bond data after aging, $\mathrm{HF}$ acid at $3 \%, 5 \%$, and $10 \%$ concentrations promoted higher values of microshear bond strength, when

Table 3 Types of failure evaluated after the bond strength tests.

\begin{tabular}{lcc}
\hline & \multicolumn{2}{c}{ Type of failure } \\
\cline { 2 - 3 } & Adhesive & Cohesive in cement \\
\hline HF1 & $34(77.3 \%)$ & $10(22.7 \%)$ \\
HF3 & $58(92.1 \%)$ & $5(7.9 \%)$ \\
HF5 & $63(87.5 \%)$ & $9(12.5 \%)$ \\
HF10 & $53(82.8 \%)$ & $11(17.2 \%)$ \\
Total & $266(85.3 \%)$ & $46(14.7 \%)$ \\
\hline
\end{tabular}
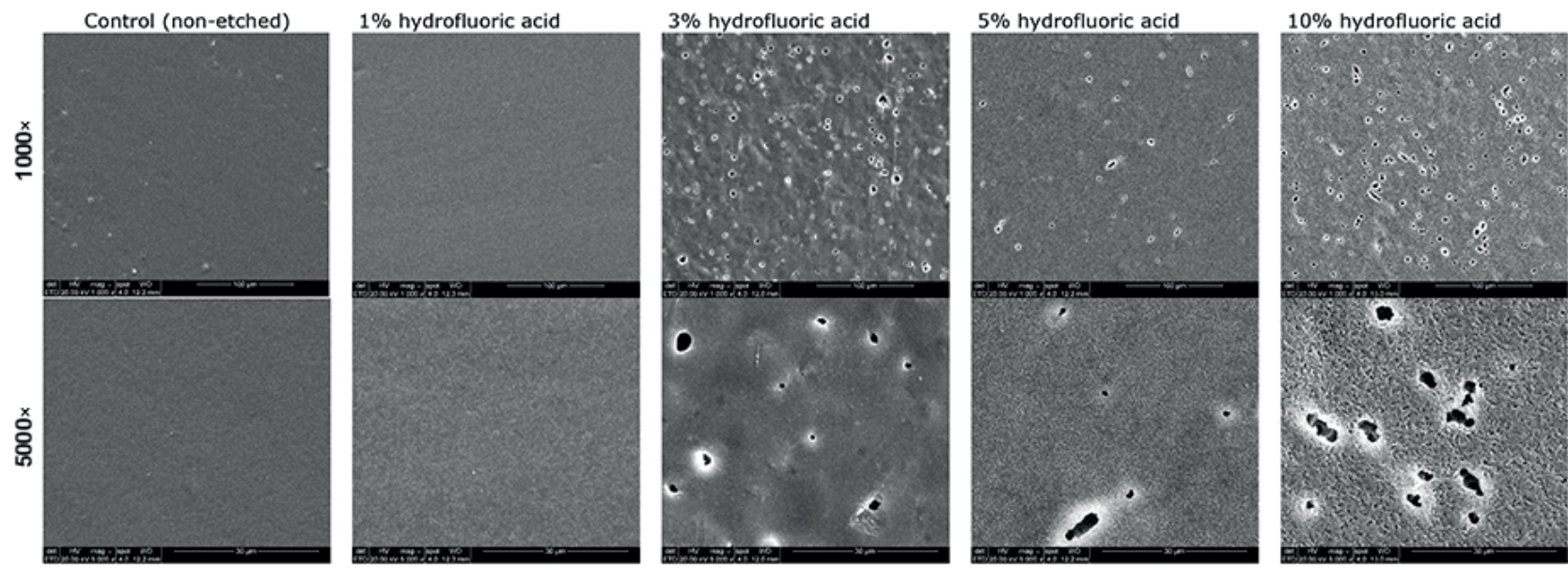

Figure 3. Representative FEG images of different ceramic surface conditioning: untreated (non-etched); etched for 20 s with HF 1\%; HF 3\%; HF 5\%; and HF 10\%. 
compared with $1 \% \mathrm{HF} \mathrm{acid,} \mathrm{which} \mathrm{had} \mathrm{a} \mathrm{high} \mathrm{percentage} \mathrm{of}$ pre-test failures during aging (90\%), evidencing the weak and unstable resin bond by etching with 1\% hydrofluoric acid, probably by slight (limited) ceramic surface alterations and absence of mechanical bond.

It is well known that micro-morphological alterations of the ceramic surfaces promote a better bond strength (5). HF acid is a modifier and an etching agent indicated for ceramics that contain silica (13) to dissolve the glassy phase, exposing the crystals and resulting in micro- and nano-morphological changes in the ceramic structure, which promotes interlocking effects (mechanical bond) $(7,8,14)$. This modification provides increased surface area, improving bonding quality, and a better contact between the ceramic material and resin cement (14). On the other hand, these surface alterations might be also related to a weakening effect on flexural strength, owing to the introduction of new defects on the surface, being crack initiators for fracture $(6,8)$. As the defect population (shape and size) is a predictor for failure of brittle materials (such as glass ceramics) (15), HF acid might play an important role in ceramic failure, since this acid promotes surface alterations of the intaglio surface of restorations, depending on their concentration and etching time (6-8). Thus, the optimal concentration should be one promoting surface alterations without weakening the ceramic.

The scientific community has been searching another option to promote topographic changes on glass ceramic surfaces owing to HF acid toxicity (10). According to Carpena and Ballarin (16), the use of HF acid by clinicians is banned in some countries, and the dental laboratory is responsible for applying HF acid as per the ceramic manufacturer's instructions (17). Besides, a recent ex vivo study showed its hazardous potential, even with concentrations of $<3 \% \mathrm{HF}$ acid (10). In this sense, some studies have tested different ceramic surface treatments as alternative ones to HF acid, however, these alternative surface treatments were not preferable to $\mathrm{HF}$ etching associated with silane application (17), or were poorly supported by the literature, thus requiring more studies. In the present study, HF acid in different concentrations $(3 \%, 5 \%$, and $10 \%)$ was able to promote surface changes, but even for the groups with higher glassy matrix removal and changes in the ceramic surface there was a significant decrease in bond strength after 150 days of storage and thermocycling.

Several factors interact in the process of establishing a strong bond between two different materials. Even with rougher surfaces to micromechanical interlocking, the chemical bond can be deteriorated by hydrolysis of siloxane bonds over time, since the resins are permeable to water (18). It is related to a fast increase in the amount of water absorbed by the composite materials causing degradation of the silane, damaging adhesion between the tested materials. Water storage and thermocycling are described as detrimental to the silane-ceramic bond (19). Also, silanized interfaces appear to be unstable in humid conditions and the silane bond was found to deteriorate in moisture. However, in vitro studies either lack the aging conditions or employ short-term water storage and/or thermocycling (20).

The results of the present study demonstrated that thermocycling reduced adhesive resistance. The pre-test failures were observed in all the tested groups, even for groups with rougher ceramic surfaces. It can be attributed to the hydrolytical deterioration of siloxane bonds in the storage period (21). In this sense, the group conditioned by $1 \%$ hydrofluoric acid lost 36 specimens $(90 \%)$, demonstrating that weak adhesion takes place when slight topographic alterations of the surface ceramic occur, even with a primer containing silane and functional monomers as MDP (10-methacryloyloxydecyl dihydrogen phosphate). The negative effect of thermal cycling on adhesion can be explained by the fact that the materials with different lineal thermal expansion coefficient presented inherent

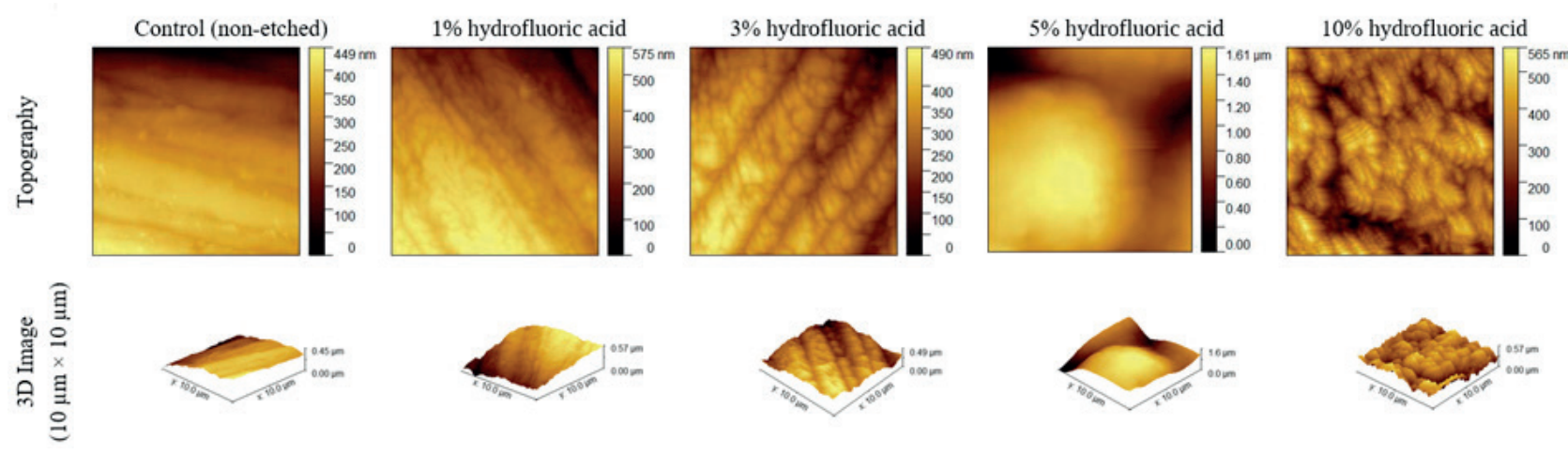

Figure 4 Representative topographic and 3D images of atomic force microscopy (AFM). 
different degrees of shrinkage and expansion - this process promotes the fatigue phenomenon of the materials, leading to rupture of the bond and interface (22). Another factor that might have contributed to the bond decrease is the small dimension of the bonded area receiving larger influence of the thermocycling effects on its surface (23). Shono et al. (24) verified that adhesive joints in samples with different dimensions presented reductions of bond strength in samples with small areas, after similar periods of storage and thermocycling.

An increase in surface area caused by HF etching induces an increase in wettability, which is associated with a lower contact angle and greater bonding potential (17). The differences showed in the contact angle measurements are explained by the higher roughness (seen by AFM: Table 2; Fig. 4), obtained in groups conditioned with acid etching at concentrations of $3 \%, 5 \%$, and $10 \%$, and by the higher and similar bond strength values. The subsequent application of a silane coupling agent after HF etching enhances the bonding potential of resin cement to lithium disilicate, in agreement with other findings $(2,4,5)$.

HF acid etching produced micro porosities, grooves, and striations (Fig. 3) by partially dissolving the glassy phase, $\vec{s}$ and higher hydrofluoric acid concentrations were able not only to promote the loss of the glassy phase, but also areas with grain pullout (5 and 10\% hydrofluoric acid). It resulted in a different surface pattern, with an increase in the size of the pores and its quantity, and elongated grooves, characteristic of this ceramic material after HF acid etching. Consequently, for the tested lithium disilicate ceramic, etching with $\mathrm{HF}$ acid at concentrations of 3\%, $5 \%$, and $10 \%$ produced higher values of roughness and increased surface modifications, as seen in FE-SEM images, and also verified by Ramakrishnaiah et al. (7).

As limitations of this current study, it can be displayed the absence of simulating intermittent clinical loading forces and environmental issues, which occur on teeth/ restorations under clinical service. Also, microshear/shear bond strength tests widely used to analyze the bond to lithium disilicate ceramics $(5,25)$ apply a monotonic load and do not cause only shear stress on the tested specimens, thus, fracture analysis is imperative for data interpretation. From this viewpoint, we excluded cohesive failures from the statistical analysis. In addition, our study did not simulate a CAD-CAM machined ceramic surface, but it can be considered as a positive condition, since the isolate effect of HF acid concentrations on adhesion could be fairly assessed.

Within the limitations of this in vitro study, it can be concluded that hydrofluoric acid at 3\%, 5\%, and 10\% concentrations promoted higher resin bond to lithium disilicate ceramic after aging. The micromorphological changes promoted by etching with these acids play a crucial role in micromechanical bond improvements, and they can be used to conditioning lithium disilicate based glassceramic. Hydrofluoric acid at $3 \%$ should be considered with caution, since it promoted slight topographical changes on the ceramic surface, and also had lower roughness values than 5 and $10 \%$ concentrations. Hydrofluoric acid at a 1\% concentration led to a very weak bond after aging.

\section{Resumo}

Este estudo avaliou o efeito de diferentes concentrações de ácido fluoridrico (HF) na resistência de união entre uma cerâmica vitrea à base de dissilicato de lítio e um cimento resinoso. Oitenta blocos cerâmicos $(12 \times 7 \times 2 \mathrm{~mm})$ de IPS e.Max CAD (Ivoclar Vivadent) foram produzidos e distribuidos aleatoriamente em 8 grupos, considerando 2 fatores de estudo: concentração de HF em 4 niveis, isto é, 1\% (HF1), 3\% (HF3), 5\% (HF5), e $10 \%$ (HF10), e armazenamento em 2 níveis, isto é, condição inicial (testes foram realizados $24 \mathrm{~h}$ após a cimentação), e envelhecidos (150 dias de armazenamento +12.000 ciclos térmicos a $5^{\circ} \mathrm{C}$ e $55^{\circ} \mathrm{C}$ ). Condicionamento ácido (20 s) foi realizado, seguido por lavagem, secagem e silanização. Quatro cilindros de cimento resinoso $(\phi=0.96 \mathrm{~mm})$ foram construídos a partir de matrizes de amido em cada amostra cerâmica $(n=40)$. Amostras cerâmicas adicionais foram condicionadas e analisadas quanto ao ângulo de contato, micro-morfologia e rugosidade. Na condição inicial (sem envelhecimento), os grupos HF3, HF5, e HF10 mostraram valores de resistência de união similares (13.9 - 15.9 MPa), e HF1 apresentou valores menores que HF5, sendo estatisticamente diferente $(p=0.012)$. Após 0 envelhecimento, todas as médias de resistência de união diminuíram estatisticamente, sendo que HF3, HF5 e HF10 foram similares e maiores que HF1 ( $p=0.0001$ ). Para o ângulo de contato, HF3, HF5 e HF10 apresentaram valores similares $\left(7.8-10.4^{\circ}\right)$, menores que os grupos HF1 e CTRL. HF5 e HF10 apresentaram superficies mais rugosas que as outras condições. Para melhores resultados de resistência de união, a cerâmica testada pode ser condicionada com ácido fluorídrico nas concentrações de 3\%, 5\% e 10\%.

\section{Acknowledgements}

CNPq (Conselho Nacional de Desenvolvimento Científico e Tecnológico, Brazil), CAPES (Coordenação de Aperfeiçoamento de Pessoal de Nivel Superior, Brazil) and FAPERGS (Fundação de Amparo à Pesquisa do Estado do Rio Grande do Sul, Brazil) Foundations supported this investigation. We thank FGM Company for manufacturing the distinct hydrofluoric acids and Ivoclar Vivadent for material donation. This paper is part of a PhD thesis submitted to the PhD Graduate Program in Oral Sciences, Prosthodontic Unit, Dental School, Federal University of Santa Maria, Santa Maria, Brazil, as part of the requirements for the PhD degree (Dr. C. Prochnow).

\section{References}

1. Gehrt M, Wolfart S, Rafai N, Reich $\mathrm{S}$, Edelhoff D. Clinical results of lithium-disilicate crowns after up to 9 years of service. Clin Oral Investig 2013;17:275-284.

2. Tian T, Tsoi JK, Matinlinna JP, Burrow MF. Aspects of bonding between resin luting cements and glass ceramic materials. Dent Mater 2014;30:e147-e162.

3. Pisani-Proenca J, Erhardt MC, Valandro LF, Gutierrez-Aceves G, Bolanos-Carmona MV, Del Castillo-Salmeron $\mathrm{R}$ et al. Influence of ceramic surface conditioning and resin cements on microtensile bond strength to a glass ceramic. J Prosthet Dent 2006;96:412-417.

4. Sundfeld Neto D, Naves LZ, Costa AR, Correr AB, Consani S, Borges $\mathrm{GA}$ et al. The Effect of Hydrofluoric Acid Concentration on the Bond Strength and Morphology of the Surface and Interface of Glass Ceramics to a Resin Cement. Oper Dent 2015;40:470-479.

5. Lise DP, Perdigão J, Van Ende A, Zidan 0, Lopes GC. Microshear Bond Strength of Resin Cements to Lithium Disilicate Substrates as a 
Function of Surface Preparation. Oper Dent 2015:40:524-32.

6. Addison 0 , Marquis PM, Fleming GJ. The impact of hydrofluoric acid surface treatments on the performance of a porcelain laminate restorative material. Dent Mater 2007;23:461-468.

7. Ramakrishnaiah $R$, Alkheraif AA, Divakar DD, Matinlinna JP, Vallittu PK. The Effect of Hydrofluoric Acid Etching Duration on the Surface Micromorphology, Roughness, and Wettability of Dental Ceramics. Int J Mol Sci 2016;17:1-17.

8. Zogheib LV, Bona AD, Kimpara ET, McCabe JF. Effect of hydrofluoric acid etching duration on the roughness and flexural strength of a lithium disilicate-based glass ceramic. Braz Dent J 2011;22:45-50.

9. Derewku MJ, Gad SC, Gavigan F, Dunn BJ. Acute dermal toxicity of dilute hydrofluoric acid. J Toxicol Cut Ocular Toxicol 1985;4: 73-85.

10. Dennerlein $K$, Kiesewetter $F$, Kilo $S$, Jäger $T$, Göen $T$, Korinth $G$ et al. Dermal absorption and skin damage following hydrofluoric acid exposure in an ex vivo human skin model. Toxicol Lett 2016;248:25-33.

11. Tedesco TK, Montagner AF, Skupien JA, Soares FZ, Susin AH, Rocha RO. Starch tubing: an alternative method to build up microshear bond test specimens. J Adhes Dent 2013;15:311-315.

12. Trindade FZ, Kleverlaan CJ, da Silva LH, Feilzer AJ, Cesar PF, Bottino MA et al. Ceramic Inlays: Effect of Mechanical Cycling and Ceramic Type on Restoration-dentin Bond Strength. Oper Dent 2016;41:E102-E17.

13. Brum R, Mazur R, Almeida J, Borges G, Caldas D. The influence of surface standardization of lithium disilicate glass ceramic on bond strength to a dual resin cement. Oper Dent 2011;36:478-485.

14. Della Bona A, Shen C, Anusavice KJ. Work of adhesion of resin on treated lithia disilicate-based ceramic. Dent Mater 2004;20:388-344.

15. Thompson JY, Anusavice KJ. Effect of surface etching on the flexure strength and fracture toughness of Dicor disks containing controlled flaws. J Dent Res 1994;73:505-510.

16. Carpena G, Ballarin A. Hydrofluoric acid - Simple things you may do not know about something you are so habituated to use. Odovtos - Int J Dental SC 2014;16:15-23.
17. Aboushelib MN, Sleem D. Microtensile bond strength of lithium disilicate ceramics to resin adhesives. J Adhes Dent 2014;16:547-552.

18. Matinlinna JP, Vallittu PK. Bonding of resin composites to etchable ceramic surfaces - an insight review of the chemical aspects on surface conditioning. J Oral Rehabil 2007;34:622-630.

19. Ho GW, Matinlinna JP. Insights on Ceramics as Dental Materials. Part II: Chemical Surface Treatments. Silicon 2011;3:117-123.

20. Ozcan $M$, Pfeiffer $P$, Nergiz I. A brief history and current status of metal-and ceramic surface-conditioning concepts for resin bonding in dentistry. Quintessence Int 1998;29:713-724.

21. Matinlinna JP, Lassila LV, Özcan M, Yli-Urpo A, Vallittu PK. An introduction to silanes and their clinical applications in dentistry. Int J Prosthodont 2004;17:155-164.

22. Brentel AS, Ozcan M, Valandro LF, Alarça LG, Amaral R, Bottino MA. Microtensile bond strength of a resin cement to feldpathic ceramic after diferente etching and silanization regimens in dry and aged conditions. Dent Mater 2007;23:1323-1331.

23. Andreatta Filho OD, Araújo MA, Bottino MA, Nishioka RS, Menezes MM. Study of thermocycling effect on the bond strength between an aluminous ceramic and a resin cement. J Appl Oral Sci 2005;13:53-57.

24. Shono Y, Terashita M, Shimada J, Kozono Y, Carvalho RM, Russell CM et al. Durability of resin-dentin bonds. J Adhes Dent 1999;1:211-218.

25. Maruo $Y$, Nishigawa G, Irie M, Yoshihara $K$, Matsumoto T, Minagi S. Does acid etching morphologically and chemically affect lithium disilicate glass ceramic surfaces? J Appl Biomater Funct Mater 2017;15:e93-e100.

Received January 22, 2018 Accepted May 14, 2018 